\title{
Kegagalan Amandemen Pasal 29 UUD 45 dan Masa Depan Syariat Islam
}

\author{
Agus Triyanta
}

The cancellation of several words in the draft of The State Establishment which is known as Jakarta Charter, i.e. the statement says on the obligation of every muslim to act according the law of Sharia, made great disappointment among Moslems. This fact shows that the eager of Indonesian Muslims to implement their sharia law is extremely huge. Therefore, during the process of constitution amendment in the reformation era, there was strong tension among representatives whether this words must be attached or not. Even though the effort also failed to remove back the words in to Pancasila, there are still some chances for hospitalization of the implementation of sharia through the local autonomy which are getting popular today.

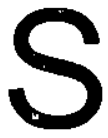

ejalan dengan upaya amandemen Undang-Undang Dasar (UUD) 1945 beberapa waktu yang lalu, untuk kesekian kalinya upaya pencantuman jaminan konstitusional secara khusus bagi Umat Islam (baca: Syariat Islam) di negeri ini mewacana dalam sebuah kontroversi dan ketegangan sosial politik yang cukup serius. Hal itu wajar, karena saat itu merupakan momentum yang pertama kali muncul, terbukanya kesempatan untuk mencantumkan beberapa kata yang lebih 50 tahun lalu dihapuskan dari Piagam Jakarta.

Sebagaimana yang banyak terungkap dalam berbagai pendapat bahwa memang ada semacam "political dissappoinment" ( kekecewaan dan penyesalan politik) dari umat Islam atas penghapusan 7 kata (menjalankan Syariat Islam bagi pemelukpemeluknya) dalam Piagam Jakarta, yang sebagaimana dikatakan oleh Sukiman sebagai gentlement agreement atau oleh Soekarno disebut dengan modus kompromis antara pihak nasionalis Islam dan nasionalis sekuler'. Kekecewaan itu mendasarkan pada alasan historis bahwa umat Islam dalam perjuangan proklamasi lebih didasari oleh cita-cita terbentuknya sebuah negara yang merdeka dengan memberikan peluang berlakunya Syariat-slam, dengan kata lain terwujudnya sebuah negara Islam².

1 Anshari, Endang S, Piagam Jakarta 22 Juni 1945 (Jakarta: Rajawali Press, 1986) halaman52-55. Lihat juga, Mangkusasmito, Prawoto, Pertumbuhan Historis DasarNegara dan Sebuah Proyeksi (Jakarta: Bulan Bintang, 1977) halaman.16-20

2 Perjuangan kemerdekaan banyak dimotori oleh perjuangan kaum santri. Ini bisa dilihat pada banyaknya pahlawan yang identik dengan ke-Islam-an, misalnya, Pangeran Diponegoro yang didampingi Kiai Sentot, Sultan Agung dari Mataram Islam, Fatahillah dari Sunda Kelapa, Ki Ageng Tirtayasa dari Banten, Kiai Zaenal Musthafa dari Tasikmalaya, belum lagi dari wilayah Kalimantan, Sulawesi dan Sumatera yang juga kaya akan pahlawan kemerdekaan. Menjelang kemerdekaan, muncullah laskar Hizbullah dan Sabilillah, tampil Jenderal 
Pertanyaannya sekarang. adalah, mengapa amandemen itu gagal dimanfaatkan untuk menampung aspirasi umat Islam dalam 'pengembalian beberapa kata' yang hilang dari Piagam Jakarta tersebut? Atau dengan pertanyaan yang lain, mengapa penolakan terhadap amandemen pasal 29 UUD 1945 itu demikian kuat? Adakah telah terjadi pergeseran konstelasi politik umat Islam? Adakah telah terjadi perubahan strategi perjuangan umat Islam setelah 50 tahun berlalu dari perdebatan Piagam Jakarta tersebut?Untuk itulah, tulisan ini mencoba untuk melihat, bagaimana amandemen pasal 29 tersebut diperdebatkan. Juga, setelah nyata bahwa upaya amandemen tersebut gagal, bagaimanakah peluang umat Islam untuk mengimplementasikan aspirasi politik mereka, keinginan-keinginan politis mereka sehubungan dengan cita-cita untuk seluas mungkin mengamalkan ajaran agama mereka, untuk mengamalkan syariat Islam.

\section{Kontroversi Amandemen Pasal 29 UUD 1945}

Ide untuk memasukkan tujuh kata yang hilang dari Piagam Jakarta dalam amandemen UUD 45 itu dicetuskan oleh beberapa partai Ișlam, yang motor utamanya adalah PBB (Partai Bulan Bintang). PBB adalah sebuah partai politik yang dipandang sebagai 'reinkarnasi' dari Masyumi, sarang dari para tokoh politik yang pada masa kemerdekaan dikenal sebagai pendukung kuat Piagam Jakarta. ${ }^{3}$

Alasan yang dijadikan landasan berpijak bagi kalangan yang pro dengan Amandemen pasal 29 adalah adanya representasi. Artinya, bahwa suatu hal yang wajar apabila umat Islam yang menjadi bagian mayoritas dari penduduk Indonesia ini kemudian menginginkan jaminan konstitusional atas berlakunya hukum agama (syariat Islam) dalam kalangan mereka. Masalah ini dipandang juga sebagai sesuatu yang selaras dengan semangat demorasi, di mana apirasi mayoritas layak diperhatikan selama tidak ada pemaksaan, jauh dari 'intimidasi ideologis' terhadap penganut agama lain. Ditambah lagi bahwa hal ini tidak akan mencederai konsep Hak Asasi Manusia dan konsep pluralisme. Pemeluk berbagai agama lain yang ada di negara ini tetap dijamin hak-haknya dan tidak akan mendapatkan perlakuan yang berbeda dengan sebelumnya. Pihak penggagas masalah ini juga menyatakan bahwa pada hakekatnya, permasalahan keinginan adanya jaminan konstitusional pemberlakuan syariat Islam ini relatif sederhana, ialah bahwa bagi umat Islam layak diberikan kesempatan untuk mempraktekkan hukum Islam, sebagaimana mereka selama ini juga sudah mempraktekkan shalat, haji dan lain sebagainya. Apa salahnya bila umat Islam menginginkan

Soedirman didikan Muhammadiyah. Sebagian fakta sejarah tersebut mengantarkan pada suatu kesimpulan adanya kontribusi historis umat Islam bagi perjuangan bangsa, bahwa perjuangan kaum santri nyata sangat dominan bagj kemerdekaan Republik Indonesia. Fakta ini bisa dilihat dalam banyak uraian pada buku. Suminto, Aqib, Politik Islam Hindia Belanda (Jakarta: LP3ES, 1985)

${ }^{3}$ Paratai Bulan Bintang didirikan bersamaan dengan masa-masa euforia politik era reformasi, di mana di dalamnya banyak berdirj (dideklarasikan) berbagai macam partai baru. Di antara deklarator partai ini adalah Hartono Marjono, seorang tokoh DDI (Dewan Dakwah Islamiyah) dan aktivis Masyumi. (http://www.tempointeraktif.com/ harian/fokus/ 39/ 2,1,34, id.html, 8-8-2000 jam17:24) 
syariat Islam berlaku bagi mereka? ${ }^{4}$

Suatu hal yang wajar apabila berbagai pihak kemudian menunjukkan reaksi atas hal ini. Kecurigaan-kecurigaan dan kekhawatiran-kekhawatiran tentu saja banyak disuarakan oleh pemeluk agama lain di Republik Indonesia ini. Akan tetapi, suatu hal yang menarik adalah bahwa pihak yang berkeberatan dengan upaya amandemen dengan pencantuman 7 kata dalam Pasal 29 UUD 1945 itu juga bukan hanya orang-orang di luar pemeluk agama Islam. Dalam kalangan umat Islam sendiri didapati berbagai segmen yang secara terang-terangan menyatakan ketidaksetujuannya terhadap amandemen tersebut. Bahkan bisa dikatakan bahwa kelompok yang menolak upaya amandemen itu cukup besar. Organisms sosial keagamaan Nahdhatul Ulama, lewat ketua umum Dewan Tanfidziyah KH. Hasyim Muzadi dan Muhammadiyah lewat ketua Umum Pimpinan Pusat nya Prof. Dr, Ahmad Syafii Ma'arif, juga tidak menyetujui rencana amandemen tersebut. ${ }^{5} \mathrm{Di}$ antara alasan yang dikemukakan oleh pihak yang kontra dengan upaya pencantuman 7 kata' tersebut apabila digeneralisir ada tiga hal. Pertama, pendapat yang menyatakan bahwa ajaran agama Islam bisa diamalkan tanpa harus secara legal formal ditetapkan oleh negara (pemerintah). Alasan ini mendasarkan pertama, pada fakta bahwa sampai saat ini ajaran Islam bisa diterapkan meskipun hanya mendasarkan diri pada dasar perundang-undangan yang berlaku. Kedua, adanya pemikiran bahwa negara tidak perlu ikut campur tangan (intervensi) dalam hal kehidupan agama. Dengan kata lain, agama harus dipisahkan dari negara, dan begitu juga sebaliknya. Pemikiran ini biasa disebut juga dengan pemikiran sekuler, yang berupaya mempolarisasikan antara agama dan negara secara ekstrim dan meletakkan masing-masing dalam posiși yang berbeda, yang antara satu dengan lainnya tidak perlu saling intervensi. Ketiga, di antara penolakan tersebut berlandaskan pada adanya kemungkinan kekhawatiran dari pihak non muslim. ${ }^{6} \mathrm{Hal}$ ini nampak bukan hanya dalam momentum tersebut, sejak kontroversi pengesahan Piagam Jakarta dalam masa kemerdekaan pun, hal sentimen SARA ini sudah menjadi perdebatan. ${ }^{7}$ Dalam kasus pengesahan Undang-Undang no 1/1974 tentang Perkawinan pun, keberatan non muslim juga nampak, dilanjutkan lagi dengan pengesahan Undang-Undang no.1 tahun 1989 tentang Peradilan Agama, hal

4 Hamdan Zoelva, salah seorang anggota Fraksi Bulan Bintang menyatakan bahwa kalangan yang menghambat pemberlakuan syariat Islam secara konstitusional, mereka terlalu memperumit masalah, terlalu terjebak dalam bayangan teoritis yang bertele-tele. Ini diungkapkan sebagai respon bagi keberatan pihak-pihak yang senantiasa menyatakan bahwa para penggagas amandemen pasal 29 tidak memiliki konsep teoritis. Hal ịni diungkapkan dalam.berbagai kesempatan, antara lain pada sumber: Ibid

${ }^{5}$ http://www.tempointeraktif.com/harian/ fokus/39/2,1,110, id.html15-8-2000/13:11 W/B

- Penulis melihat, bahwa berbagai alasan keberatan tersebut tidak bisa dilepaskan keterkaitannya dengan ide-ide Islam kontemporer yang muncul, sejak dari "Islam Yes dan Partai Islam No"-nya Nurcholis Madjid, "Pribumisasj Islam"nya Gus Dur, hingga "Islam Liberal"nya Ulil Abshar Abdalla. Ketiga mainstream pemikiran tersebut dipandang cukup representatif untuk menjadj fundamen dari ketidaksetujuan pihak antại Piagam Jakarta. Ini sebagai konsekuensi dari pemikiran yang menolak Islam yang simbolis atau formalis.

7 Anshại, ibid. 
yang sama juga terjadi. Dan yang terakhir belum lama ini adalah tentang pengesahan Undang-Undang Sisdiknas.

Ini tentunya merupakan suatu hal yang sangat menarik, di mana cara berpikir sebagian (besar) umat Islam, sebagai terrefleksi dalam banyak partai Islam atau partai terbuka berkonstituen umat Islam, ternyata berbeda dengan pola berpikir umat Islam di masa kemerdekaan, sekaligus, tentu saja, berbeda dengan segemen muslim penuntut amandemen. Paradigma Islam kultural -meminjam istilah Nucholis, atau Islam pribumi - dalam istilah Abdurrahman Wahid, atau Islam kontekstual -dalam istilah Munawir Sjadzali, atau Islam Liberal -dalam istilah UIil Abshar Abdala dkk, telah menggeser paradigma Islam formalis atau simbolis yang menginginkan pencantuman jaminan syariat Islam secara legal simbolistik. Tidak tempatnya di sini memperdebatkan antara kedua macam paradigma tersebut. Namun yang menjadi sebuah catatan penting adalah bahwa pada akhirnya, meskipun banyak para tokoh umat Islam berada dalam pemerintahan Republik Indonesia, ${ }^{B}$ namun keinginan untuk menambahkan beberapa kata dalam pasal 29 UUD 1945 tersebut gagal.

Dengan telah gagalnya amandeman pasal 29 tersebut, selanjutnya yang perlu dilihat adalah, dalam kondisi ketiadaan 7 kata tersebut, sejauh mana peluang yang tersedia bagi umat Islam untuk bisa mengamalkan ajaran Islam seluas-luasnya. Atau dengan kata lain, sejauh mana syariat Islam dapat dimplementasikan bagi kalangan umat Islam.

\section{Syariat Islam minus Jaminan Konstitusional}

UUD 1945 merupakan sumber hukum konstitusional tertinggi dalam hirarki perundang-undangan di indonesia.Sehingga, sesuatu yang telah tertera dalam UUD 45 merupakan suatu ketentuan hukum yang tidak bisa dibatalkan kecuali dengan proses amandemen. Dalam hal jika pencantuman jaminan berlakunya syariat Islam ditulis di dalamnya, akan berefek pada seluruh aturan perundang-undangan di bawahnya. Bahkan, corak sebuah negara akan ditentukan dengan apa yang tertulis dalam konstitusi tersebut. Amerika Serikat misalnya, didasarkan atas apa yang tertera di dalamnya, akan dikenal sebagai negara yang liberal demokratik, negara yang sekuler. ${ }^{9}$ Sebaliknya, negara Yahudi Israel, akan dikenal sebagai negara Yahudi modern, dikarenakan di dalamnya dicantumkan kata-kata yag menunjukkan bahwa negara didasarkan atas agama dan tradisi Yahudi. ${ }^{10}$ Malaysia, misalnya, juga akan dilihat sebagai negara Islam yang relatif 'kental' dikarenakan dalam konstitusinya menyatakan bahwa agama negara adalah

${ }^{8}$ Kabinet Gotong Royong menampakkan komposisi yang memberikan banyak tempat bagi tokoh Islam. Hamzah Haz (wakil Presiden), Amin Rais (Ketua MPR), Akbar Tanjung (Ketua DPR), serta berbagai menteri di dalamnya adalah para tokoh yang berbasis pada; Muhammadiyah, Nahdhatul Ulama, Keluarga Alumni HMI, serta berbagai organisasi sosial keagamaan Islam lainnya.

${ }^{9}$ Ini bisa dilihat dalam the Declaration of Independence serta konstitusi Amerika Serikat. The Constitution of The United States, dalam Constitutions of the Countries of the World, Gisbert H. Flanz, ed, New York, Oceana Publications Inc.Dobbs Ferry, 1992

${ }^{10}$ Bisa dilihat dalam 'The Declaration of the Establishment', dalam, Henry E.Baker, The Legal System of Israel (London: Israel Universities Press, 1968) halaman. 2 
agama Islam. ${ }^{11}$ Meski demikian, warga negara beragama non Islam juga tidak mendapat perlakuan yang sifatnya menentang HAM. Bahkan, tetap saja, bahwa pemberlakuan syariat Islam pun ternyata bervariasi antara satu negara federal dengan negara federal yang lain. Negara Bagian Kelantan dan Trengganu misalnya, lebih ketat dalam menerapkan syariat Islam dibandingkan beberapa negara bagian yang lain. ${ }^{12}$ Sama halnya, Brunei Darussalam, menjadi sebuah negara islam dengan jaminan konstitusional sejak dicantumkannya jaminan keagamaan dalam konstutusinya, sebagaimana termaktub dalam teks Deklarasi Kemerdekaan Brunei $1984 .{ }^{13}$ Karena itulah, upaya pencantuman 7 kata dalam UU tersebut dipandang sangat strategis, karena akan menentukan jenis sebuah negara; afiliasi negara terhadap agama tertentu. Sebaliknya, dengan tanpa dicantumkannya jaminan konstitusional atas pemberlakuan/pengakuan agama tertentu berarti negara telah lepas dari unsur keagamaan, dengan kata yang lebih ekstrem, sebuah negara telah menempuh jalan yang sekularis, meletakkan agama di liur konteks sistem kenegaraan. Agama ada dalam wilayah personal (private domain), jauh dari interest umum (public domain). ${ }^{14}$

Pertanyaannya kemudian adalah, apakah dengan kegagalan itu akan berakibat negatif bagi bagi kebebasan umat Islam untuk mengamalkan agamanya, menerapkan syariat yang mereka yakini?.

Jawaban atas pertanyaan di atas tidak bisa dijawab secara hitam-putih, namun harus dilihat dalam sebuah bentangan antara ekstrimitas sekularnya negara dengan ekstrimitas penjunjung-tinggian asas Ketuhanan dalam bernegara. Di antara kedua ujung tersebut, akan bisa dilihat, sejauh mana ruang gerak pemberlakuan syariat Islam akan bisa diimplementasikan.

\section{'Entry point' bagi Kebebasan Pengamalan Syariat Islam}

Apakah pengaruh signifikan dari kegagalan upaya umat Islam memperjuangkan amandemen pasal 29 UUD 1945? Secara teoritis, dalam konteks ketatanegaraan hal itu memiliki pengaruh yang sangat besar. Dengan eskplisitas pernyataan bahwa "dengan kewajiban menjalankan syariat Is-

"Antara lain terrefleksi dalam, Kurnpulan Makalah pada Intemational Confrence on the Administration of Islamic Law in Islamic States. (Kualalumpur: Islamic Understanding Institute, 1995), juga pada, Hooker, MB, Islamic Law in Southeast Asia (Oxford: Oxford University Press, 1984) halaman.143.

12 Konstitusi Federal pasal $4(1)$ menyebutkan :" Islam adalah agama negara, tetapi agama lain bebas dipraktekkan di seluruh wilayah federasi berdasarkan semangat perdamaian dan keselarasan ". Dalam...

${ }^{13}$ Dalam Deklarasi Kemerdekaan Brunei 1984 dinyatakan: "Negara Brunei Darussalam adalah dengan izin serta limpah Karunia Allah SWT, akan untuk selamalamanya kekal menjadi sebuah Negara Melayu Islam Beraja yang merdeka, berdaulat dan demokratik, bersendikan kepada ajaranajaran agama Islam menurut Ahlu Sunnah Wal Jamaah dengan berasaskan keadilan dan amanah dan kebebasan.". Antara lain terrefleksi dalam, Kumpulan Makalah pada International Confrence on the Administration of Islamic Law in Islamic Stafes.

${ }^{14}$ Peter L. Berger mendefinisikan bahwã sekularisasj adalah proses yang membuat berbagai aspek dalam hidup dan budaya terjauhkan dari dominasi pranata dan simbul agama' ('the process by which sectors of society and culture are removed from the domination of religious institutions and symbols'). Dalam, Peter L. Berger, The Sacred Canopy, Elements of a Sociological Theory of Religion ( New York-London : Anchor Book Doubleday, 1990) halaman.107 
lam bagi pemeluk-pemeluknya", ${ }^{15}$ berarti bahwa negara akan bertanggung jawab dalam mewujudkan pengamalan syariat Islam bagi para penganut agama Islam. Bentuk tanggung jawab pemerintah adalah membentuk komisi tertentu, atau lembaga tertentu yang memiliki kewenangan secara koersif dan repressif melakukan syariah enforcement. Pemerintah, pada akhirnya bukan sekedar memiliki porsi yang sangat besar dalam mengintervensi pengamalan keagamaan seseorang, namun menjadi penanggung jawab penuh atas pengamalan syariat Islam. Ini adalah suatu hal yang sangat tidak dikehendaki oleh kalangan Islam kultural.

Kemudian, apakah pengaruh dari ketiadaan 7 kata tersebut? Ketiadaan pencantuman beberapa kata tersebut, meskipun cukup besar pengaruhnya bagi implementasi ajaran syariat Islam di Indonesia, namun dengan ketiadaannya, ada beberapa hal yang masih bisa dijadikan sebagai landasan optimalisasi penerapan syariah Islam. Artinya, masih ada beberapa sisi aspek politis yang penting untuk diperhatikan bagi umat Islam dalam hal ini, yaitu, sila pertama Pancasila, pasal 29 dari UUD 1945, serta atribut negara Indonesia sebagai negara Islam yang diberikan oleh dunia Internasional. Sejauhmana masingmasing aspek tersebut bermakna bagi upaya optimalisasi penerapan syariat Islam, bisa dijelaskan sebagai berikut:

Pertama, sila pertama Pancasila. Munawir Sjadzali, pada saat menjabat sebagai menteri agama pernah memberikan statemen bahwa Indonesia tidak akan pernah menjadi agama sekuler. Jaminan dari pernyataan itu adalah adanya sila pertama Pancasila, "Ketuhanan Yang Maha Esa dan Pasal 29 UUD $1945^{\prime \prime 6}$. Apabila demikian halnya, yang menjadi pertanyaan selanjutnya adalah sejauh mana kekuatan sila pertama dalam Pancasila tersebut mampu memberikan garansi bagi kebebasan mengamalkan ajaran syariat Islam. Biasakah, dengan berlandaskan pada sila pertama tersebut umat Islam menuntut berbagai aransement birokratis bagi upaya mengamalkan agamanya?.

Pancalisa, sebagaimana yang telah disadari adalah sebagai landasan ideologis dan sekaligus menjadi hukum terttinggi dalam hirarki perundang-undangan di Indonesia. Ini, berimplikasi pada harus adanya pengakuan bahwa semua aturan perundangundangan di bawah dasar negara, tidak boleh bertentangan, memperlemah atau menafikan dari apa yang tersurat dari sila pertama dalam Pancasila tersebut. Tidak ada alasan yuridis yang bisa dibenarkan apabila ada sebuah aturan di bawahnya yang menghalangi upaya penerapan ajaran agama. Itu pun, akan menjadi lebih kuat apabila didasarkan pada uangkapan bahwa Pjagam Jakarta (Jakarta Charter)

${ }^{15}$ Rumusan itu terkenal dengan Piagam Jakarta, yang telah disepakati oleh Panitia Kecil pada șidangnya tanggal 22 Juni 1945. Panitia Kecil itu bertugas untuk mendapatkan suatu modus, suatu persetujuan antara pihak Islam dan pihak kebangsaan. Anggota Panitia Kecil itu sendiri ada 9 orang sebagai berikut; Mohammad Hatta, Mohammad Yamin, Subardjo, Maramis, Soekarno, Kiai Abdul Kahar Moezakkir, Wachid Hasjim, Abikusno Tjokrosujoso, dan Hadji Agus Salim. Lihat dalam, Saafroedin Bahar, dkk (editor), Risalah Sidang Badan Peneylidik Usaha-Usaha Persiapan Kemerdekaan Indonesia (BPUPKI), Panitia Persiapan Kemerdekaan Indonesia (PPKI) (Jakarta: Sekretarian negara Republik Indonesia) 1992, hlm.81

16 Asy'arie, Musa, ed. Agama Menyongsong Era Tinggal Landas (Yogyakarta: IAIN Sunan Kalijaga Press, 1988) hal. 1-10 
merupakan suatu rangkaian yang tidak dapat dipisahkan dari Pancasila. Tentu saja pertanyaan berikutnya adalah, apakah sebenarnya yang dimaksudkan dengan bagian tak terpisahkan tersebut? ${ }^{17}$

Pertanyaan tersebut bisa dijawab dengan menginterpretasikan konteks yang berkembang pada saat proses penyususan dasar negara berlangsung. Sebagaimana dalam dokumen sejarah yang ada, bahwa Piagam Jakarta merupakan suatu hasil dari BPUPKI pada sidangnya tanggal 22 Juni 1945. Dengan berbagai alasan yang pada muaranya adalah demi integrasi bangsa, maka kemudian 7 kata dalam piagam Jakarta itu dihapus, sehingga yang tetap disyahkan sebagai dasar negara adalah Pancasila sebagaimana yang ada sekarang ini. Penghapusan tersebut, yang tentu saja merupakan suatu putusan yang harus diterima dengan berat hati dari umat Islam, komponen terbesar dalam perjuangan negara Indonesia. Memahami keberatan tersebut, maka kemudian diberikankah sebuah ungkapan bahwa Piagam Jakarta merupakan bagian tak terpisahkan dari Pancasila, serta ungkapan bahwa kesediaan pihak Islam untuk merelakan hilangnya tujuh kata tersebut merupakan 'hadiah terbesar dari umat Islam untuk bangsa Indonesia'. ${ }^{18}$ Sehingga, bagian tak terpisahkan bisa dimaknai sebagai suatu nilai yang melekat, suatu nilai yang bisa memberikan penjelasan bagi sila pertama dalam Pancasila. Dengan kata lain, tafsiran dari sila pertama antara lain bahwa ada kebebasan bagi umat Islam untuk menjalankan syariat Islam. Atas dasar itulah, maka peluang pemberlakuan syariat Islam pun, tidak menghadapi hambatan yuridis.

Kedua, Pasal 29 UUD 1945. Pasal 29 tentang Agama, berbunyi: "(1). Negara berdasar atas Ketuhanan Yang Maha Esa.
(2) Negara menjamin kemerdekaan tiap-tiap penduduk untuk memeluk agamanya masing-masing dan untuk beribadat menurut agamanya dan kepercayaannya itu". Dengan tanpa amandemen sekalipun, pernyataan dalam pasal 29 itu sudah sangat jelas memberikan jaminan bagi pelaksanaan ajaran agama. Bedanya, dalam pasal tersebut memang tidak memberikan keistimewaan secara eksplisit terhadap agama Islam sebagai agama yang dominan (dianut oleh mayoritas penduduk). Ketika kebebasan untuk beribadah menurut agama itu menjadi hak bagi setiap warga negara, maka upaya menjalankanl syariat Islam pun menjadi suatu hak yang harus diberikan bagi umat Islam. Hal itu disebabkan karena pengamalan syariat Islam'merupakan suatu bentuk ibadah dalam Isłam, di mana ibadah itu sendiri adalah suatu merupakan pilar utama Islam. Sehingga, meski tidak secara khusus dan eksplisit, namun pasal itu tetap merupakan sebuah pintu bagi umat Islam untuk diberikan kebebasan menerepkan syariat Islam.

Ada dua hal yang bisa ditarik darj ungkapan dalam Pasal 29 di atas, yaitu, bahwa Indonesia tidak bisa menafikkan aspek ajaran agama dalam kehidupan masyarakatnya, sehingga, sebenarnya dimungkinkan bahwa pemerintah memberikan kebijakan tertentu bagi pelaksanaan syariat Islam atas pertimbangan tertentu pula. Lain dari pada itu, ungkapan pasal tersebut juga tidak kalah jelasnya dengan jaminan kebebasan beragama dan berkeyakinan (freedom of religion and freedom of belief) sebagaimana terdapat dalam The Universal Declaration of Human Rights. ${ }^{19}$

${ }^{17}$ Anshari, Ibid.

18 Ibid, halaman 60

${ }^{19}$ Edge, lan, The Universal Declaration of human Rights, ( New York: New York University Press, 1992). 
Dimungkinkannya pengamalan syariat Islam juga nampak dari kata-kata "beribadat menurut agama dan kepercayaannya itu". Hal itu disebabkan oleh sangat terbuka dan elastisnya makna atau interpretasi dari kata "ibadah". Islam memiliki konsep ibadah yang yang spesifik. Pengamalan syariat Islam, adalah bagian dari ibadah itu..$^{20}$ Karena, dalam arti luasnya, ibadah bukan hanya ritus yang spesifik hubungan Tuhan dengan manusia, namun keseluruhan aktivitas hidup seorang hamba adalah bisa dimaknai sebagai ibadah.

Ketiga, identifikasi masyarakat Islam bahwa Indonesia adalah sebuah negara Islam. Label atau predikat bahwa Indonesia adalah negara Islam merupakan sebuah permakluman internasional yang selama ini sudah berlaku. Indonesia bukan saja telah tergabung dalam anggota Organisasi Konferensi Islam (OKI), namun telah menjadi salah satu negara pioner dalam gerakan tersebut. Meskipun istilah negara Islam (Islamic state) atau negara muslim (moslem country) itu sendiri masih menjadi perdebatan, namun tetap saja predikat tersebut sangat bermakna.

Meskipun 'klaim' internasional bahwa Indonesia sebagai sebuah negara Islam itu tidak memiliki landasarn yuridis yang sifatnya legally binding (mengikat secar hukum), namun tetap saja hal itu sangat penting maknanya. Karena, pengakuan dunia internasional terhadap eksistensi sebuah negara dengan segala atribut yang menyertainya merupakan salah satu elémen penting bagi negara itu sendiri. Sehingga, hal itu bisa dikatakan sebagai suatu 'modal' utama umat Islam untuk mendapatkan hakhak politis yang mencukupi sebagai landasan bagi kebebasan pengamalan syariat mereka.

Lebih dari itu, 'klaim' tersebut bukanlah sesuatu yang lahir tanpa sebab dan konteks yang melatarbelakanginya. Secara historis dan kultural, 'klaim' tersebut memang layak disandang. Dengan kata lain, kegagalan amandemen pasal 29 secara politik internal memang menyisakan banyak kekecewaan bagi sebagian umat Islam, namun di sisi lain, secara 'klaim' yang telah secara inheren melekat pada nama Indonesia merupakan fakta politik yang tidak bisa dibantah.

Dengan dasar ketiga hal tersebut, maka keharusan pemerintah untuk mengakomodasi berbagai kehendak umat Islam untuk memfasilitasi beberapa aspek pembangunan yang berkait dengan ajaran Islam menjadi wajar. Karena itulah, perkembangan lembaga ekonomi/keuangan Islam juga harus direspon oleh pemerintah. Pemerintah harus memberikan regulasi untuk hal tersebut agar bisa tercipta ketertiban dalam penyelenggaraannya. Dalam kasus upaya penciptaan kelengapan birokratis untuk perbankan syariah, serta perangkat perundang-undangan yang diperlukan, adalah sebuah keharusan bagi pemerintah jika memang demokrasi masih harus dihormati.

\section{Otonomi Daerah dan Optimisme Pemberlakuan Syariah}

Ada sebuah fenomena yang massif di berbagai daerah di wilayah Republik Indonesia, ialah adanya 'greget' untuk penegakan atau pemberlakuan syariat islam dalam berbagai aktivitasnya. Ini terjadi khususnya di daerah-daerah di mana umat

${ }^{20}$ Dalam teori autoritasnya HAR Gibb dinyatakan, bahwa apabila seseorang memeluk agama Islam, maka secara otomatis hukum Islam akan terlekat pada dirinya. Ichtiyanto, dalam, Arif, Edi Rudiana, peny, Hukum Islam di Indonesia, cet. I, (Bandung: Pustaka Rosdakarya, 1990) h. 19 
Islam menduduki jumlah terbesar dalam komposisi statistik kependudukan. Setelah diberikannya otonomi khusus pada NAD (Nangroe Aceh Darussalam) yang berupa kelonggaran dalam penegakan syariat Islam, ternyata kemudian di berbagai daerah bisa dilihat kegairahan untuk menuju hal yang sama. Di beberapa daerah di Sulawesi, hal ini nampak cukup jelas. Keberadaan Komite Penegakan Syariat Islam di Makassar menunjukkan adanya animo ke arah pemberlakuan syariah Islam. Cianjur, adalah contoh lain untuk hal serupa untuk daerah yang berada di Pulau Jawa ${ }^{21}$.

Hal tersebut, selain menunjukkan adanya potensi bagi pemberlakuan syariat Islam, namun juga sekaligus bisa menunjukkan, bahwa kegagalan amandemen terhadap Pasal 29 UUD 1945 merupakan salah satu tidak adanya kesejalanan antara aspek sosiologi hukum dengan political will dari para wakil rakyat, sekaligus merupakan suatu langkah yang unik, ialah bahwa meskipun tidak ada legalitas bagi kepentingan penegakan syariah Islam secara khusus, namun, meski masih dalam taraf yang relatif elementer, upaya pemberlakuan syariat Islam menunjukkan harapan yang menjanjikan.

Persoalan yang muncul kemudian adalah, sejauh mana kekuatan Perda (Peraturan Daerah) tersebut dalam menjembatani keinginan untuk pemerlakuan syariat Islam? Memang, bahwa dalam sistem pemerintahan dengan otonomi luas, berbagai daerah dimungkinakan untuk memberikan aturan-aturan yang mengakomodasi keinginan masyarakat lokal, yang tentu saja tidak boleh bertentangan dengan prinsip-prinsip demokrasi dan ketentuan-ketentuan perundang-undangan di atasnya. Hal ini sebenarnya juga bisa dilihat dengan kasus di Malaysia. Meskipun Malaysia adalah sebuah negara federal,namun paling tidak bisa memberikan inspirasi bagaimana kekhususan daerah bisa diatur. Pemberlakuan syariat Islam di Malaysia, juga bervariasi antara satu negara federal yang satu dengan yang lain. Artinya, pertimbangan aspek sosiologis tetap menjadi perhatian meski Malaysia secra konstitusional telah mencantumkan agama Islam sebagaj agama negara. Kelantan adalah salah satu negera federal yang paling ketat dalam memberlakukan syariat Islam. Dengan demikian, dengan memperhatikan aspek sosiologis di masing-masing daerah, pemberlakuan syariat Islam bisa diintrodusir.

Hal lain yang perlu diperhatikan di sini adalah mekanisme yang diperlukan mengakomodasi pemerlakuan syariat Islam. Mengingat bahwa fungsi penetapan peraturan daerah ada pada tangan Dewan Perwakilan Rakyat Daerah (DPRD), maka upaya ini tentu saja harus memenuhi persyaratan legislasi. Artinya, hanya koridor demokrasi yang bisa digunakan untuk melahirkan sebuah Perda yang aspiratif bagi penegakan syariat. Artinya, pemberdayaan dan sosialisasi yang baik dari berbagi eksponen penggagas pemberlakuan syariat Islam akan sangat berpengaruh. Dengan demikian, upaya ini selanjutnya akan benarbnenar merefleksikan adanya aspirasi yang bersifaty bottom-up, bukan top-down.

Berkenaan dengan cakupan aspek yang bisa diatur dengan pemberlakuan syariat Islam melalui perda ini tentu saja halhal yang tidak bertentangan dengan pertauran peundang-undangan dari tingkatan yang lebih tinggi dalam hirerakhi perundang-undangan. Ini, tentu saja akan sangat dipengaruhi oleh sejauh mana kesiapan aparat pemerintah setempat.

${ }^{21}$ gejala ini marak dengan adanya UU Otonomi daerah 1999. 
Karena, semua aturan yang ada dalam Perda tersebut tidak akan inforceable apabila tidak didukung oleh aparat yang memadahi, baik dari segi kualitas maupun kuantitas.

Suatu hal yang harus diperhatikan dalam kaitannya dengan kian maraknya berbagai upaya pemberlakuan syariat Islam -meski masih dalam bentuk yang elementer, adalah modus untuk menjadi solusi agar upaya tersebut tidak menimbulkan friksi dalam masyarakat sehingga justru akhirnya kontraproduktif dengan penegakan syariat Islam.

Atas dasar dari sila pertama Pancasila tersebut, dilanjutkan dengan pasal 29 dari UUD 1945, serta legitimasi internasional atas 'negara Islam/Muslim' nya Indonesia, maka kegagalan umat Islam untuk memperjuangkan masuknya 7 kata ke dalam pasal 29 UUD 1945, bisa dicarikan jalan keluarnya melalui perda (Peraturan Daerah) di berbagai Daerah Tingkat II yang secara sosiologis memungkinkan untuk ditegakkan syariat Islam. Dengan adanya otonomi daerah, ternyata memberikan peluang bagi berbagai daerah untuk memasukkan aspirasi religiusitas ke dalam kehidupan politik-kemasyarakatan yang ada.

Apakah Perda-perda semacam itu melanggar? Dengan melihat pada berbagai landasan sebelumnya, bisa disimpulkan bahwa tidak ada pertentang sedikit pun antara UUD 1945 dengan Perda yang baru dibuat oleh berbagai propinsi tersebut selama tidak bertentang dengan pasal-pasal lain dalam UUD 1945, ataupun peraturanperaturan peundang-undangan yang lebih kuat, termasuk antara lain yang cukup sensitif adalah bagaimana pihak non muslim tetap diberikan kemerdekaan dan hak-hak mereka. Karena sekali lagi harus diingat bahwa pengekan syariat Islam ini pada dasarnya adalah untuk memberikan kesempatan pada umat Islam agar bisa mjl agama dan kepercayaan mereka.

\section{Kesimpulan}

Dari pemaparan dan analisis di depan, bisa ditarik beberapa kesimpulan penting sebagai berikut:

Pertama, hilangnya tujuh kata dari Piagam Jakarta, merupakan sebuah modus solusi yang sangat mengecewakan umat Islam. Tujuh kata tersebut sudah lolos dipertahankan dalam dua kali sidang BPUPKI, namun ternyata dalam rapat pengesahan undang-undang negara, hal itu akhirnya terhapus dalam sidang PPKI tanggal 18 Agustus 1945. Momentum ini bisa dinilai sebagai sebuah bukti bahwa memang aspirasi umat Islam untuk diberikan peluang mengamalkan ajaran agamanya sangat kuat, meski akhirnya tidak tercapai.

Kedua, munculnya lagi wacana ini dalam rangkaian amandemen terhadap UUD 1945 beberapa saat yang lalu, meskipun tetap masih gagal, menunjukkan hal seperti pada kesimpulan dalam poin pertama. Hanya, bahwa pihak-pihak yang berkeberatan terhadap amandemen ini ternyata banyak juga yang berasal dari pihak Islam. Artinya, ini menunjukkan telah terjadinya pergeseran paradigma dalam pemikiran agama dan negara di kalangan umat Islam.

Ketiga, bagi sebagian umat Islam yang tetap menginginkan upaya penegakan syariat Islam, ternyata dengan terjadinya kegagalan di dua tahap mekanisme parlementer tersebut, tidak berarti menutup sama sekali peluang pengamalan ajaran syariat Islam. Dengan mendasarkan pada sila pertama Pancasila, Pasal 29 UUD 1945 serta adanya 'pengakuan' internasional bahwa Indonesia adalah negara Islam, umat 
Islam di Indonesia bisa melakukan upaya optimalisasi penerapan syariat islam. Terlebih, dengan adanya otonomi luas bagi berbagai daerah di Indonesia, upaya ke arah tersebut lebih memiliki peluang.

\section{Daftar Pustaka}

Anshari, Endang S, 1986, Piagam Jakarta 22 Juni 1945, Jakarta: Rajawali Press.

Edge, lan, 1992, The Universal Declaration of human Rights, New York: New York University Press,

Arif, Edi Rudiana (peny), 1990, Hukum Islam di Indonesia, cet. I,Bandung: Pustaka Rosdakarya.

Asy'arie, Musa, ed, 1988, Agama Menyongsong Era Tinggal Landas Yogyakarta: IAIN Sunan Kalijaga Press.

Gisbert H. Flanz, ed,1992, The Constitution of The United States, dalam Constitutions of the Countries of the World, New York: Oceana Publications Inc. Dobbs Ferry,

Henry E.Baker, 1968, The Legal System of Israel London: Israel Universities Press,

Hooker,MB, 1984, Islamic Law in Southeast Asia, Oxford: Oxford University Press,
Mangkusasmito, Prawoto, 1977, Pertumbuhan Historis Dasar Negara dan Sebuah Proyeksi , Jakarta: Bulan Bintang.

Peter L. Berger, 1990, The Sacred Canopy, Elements of a Sociological Theory of Religion.New York-London: Anchor Book Doubleday.

Syafroedin Bahar, dkk (editor),1992, Risalah Sidang Badan Peneylidik UsahaUsaha Persiapan Kemerdekaan Indonesia (BPUPKI), Panitia Persiapan Kemerdekaan Indonesia (PPKI), Jakarta: Sekretarian negara Republik Indonesia.

Suminto, Aqib, 1985, Politik Islam Hindia Belanda. Jakarta: LP3ES.

Kumpulan Makalah, 1995, pada International Confrence on the Administration of Islamic Law in Islamic States. Kualalumpur: Islamic Understanding Institute.

http://www.tempointeraktif.com/harian/ fokus/39/2,1,34, id.html, 8-8-2000/ 17:24

http://www.tempointeraktif.com/harian/ fokus/39/2, 1, 110, id.html15-8-2000 / 13:11 